Article

\title{
The German Permaculture Community from a Community of Practice Perspective
}

\author{
Raissa Ulbrich * (1) and Claudia Pahl-Wostl \\ Institute of Environmental Systems Research, Osnabrück University, Barbarastr. 12, 49069 Osnabrück, Germany; \\ cpahlwos@uni-osnabrueck.de \\ * Correspondence: raissa.ulbrich@uni-osnabrueck.de
}

Received: 28 January 2019; Accepted: 21 February 2019; Published: 26 February 2019

\begin{abstract}
The permaculture community is a grassroots initiative that challenges current mainstream practices. Such grassroots initiatives are seen as promising incubators of learning processes that can guide transformations. However, there is ambivalence between the wish of grassroots initiatives to reach people and reoccurring claims of insularity. We use the concept of Communities of Practice to answer important questions concerning community dynamics and learning processes: How are individual perspectives turned into a joint endeavour? How do the community and its respective relation to its members affect the interactions with external actors? Drawing on qualitative data from twelve semi-structured interviews with teachers from Germany's biggest education body on permaculture, the Permakultur Akademie, our goal was to gain insights into the community's self-organisation and learning interfaces. Findings suggest that the German permaculture community displays key characteristics of a Community of Practice with developed shared values as well as education and organisational structures, while being embedded in an international community. At the time of the research, internal challenges were the absence of a common strategy that effectively linked individuals to coordinated activities. The results led to implications for a more diverse use of the concept to inform actions and several questions for future research.
\end{abstract}

Keywords: boundary processes; community of practice; grassroots initiatives; permaculture; qualitative methods; social learning; sustainability transitions; transformation

\section{Introduction}

Despite more available information than ever before [1], humanity has transgressed the "safe operating space" of the planet regarding three out of nine key Earth system processes, being at risk to trespass several other biophysical boundaries [2]. Unavoidably depending on functioning ecosystems, human society on Earth is in serious danger of causing unacceptable global environmental change [2-4] tipping the complex Earth system into an uncertain future state [5].

Hence, many disciplines acknowledge that fundamental transformations on all levels of society are required $[3,6,7]$. This relates to radical and interlinked shifts in underlying institutions, namely the informal and formal rules that govern human behaviour [8-10] as well as in corresponding social practices [11-13]. As a result, the notion that social change can be facilitated by social innovation [14-16] has attracted increasing interest in both resilience $[4,17,18]$ and transitions research $[6,11,19,20]$. Olsson et al. state that the ecological challenges urge for social innovations that transcend strategies which reduce harm and rather foster the ability to lever transformative changes "that help humanity become a positive force on the planet and create a good Anthropocene" [4] (p. 3). Calls for transformative change entail the question, how fundamental change can be consciously created, "transforming our taken-for-granted frames of reference (meaning perspectives, habits of mind, mind-sets) to make them more inclusive, discriminating, open, emotionally capable of change, and 
reflective so that they may generate beliefs and opinions that will prove more true or justified to guide action" [21] (pp. 7-8).

Correspondingly, a growing body of academic literature deals with grassroots initiatives developing from the bottom-up and their potential to support social innovation and "future sustainability of society as a whole" [14] (p. 1). As of yet, in terms of analytical means, these findings hint at a void between individual-centred approaches on the one hand and the ones that focus on the interplay of communities and networks on the other hand. Moreover, in practice, there is an ambivalence between the wish of grassroots initiatives to reach people with their message and reoccurring claims of insularity and an inward-looking perspective [12,22-24].

Even though the perspective of socio-technical transitions emerged as a reaction to path dependencies, it has preserved a prevalent focus on the reproduction of rules and meanings [14]. Little has been done to conceptualise learning processes which essentially lie at the core of transition processes [25]. Consequently, transitions studies still lack analytical approaches that focus on the actual production of knowledge, practices and institutions, truly accounting for the emergence of radical alternatives and the relational and systemic nature of the associated processes of transformation towards sustainable development [11,24-27]. For a more appropriate analysis of social innovation and the emergence of alternative practices, Howaldt and Schwarz stress the importance of more rigorous analysis of reflexive social learning processes, self-organisation and communication processes [14]. At the same time, it is emphasised that adequate analytical approaches need to be developed sensitive to alternative ideas and practices for social change [27].

In this context, adding to the analysis of alternative ideas and practice, we propose that the concept of social learning systems comprised of Communities of Practice (CoP) offers complementary value to assess conditions of learning processes in social networks with a systemic perspective [28-30]. A CoP is a conception of a formal or informal network of people sharing values, interests, expertise and practices. Through ongoing interactions, negotiations of meaning and activities in the community, knowledge and practices are refined, shared and developed [28]. CoPs are a prominent concept to describe the social and cultural dimensions of innovation and knowledge creation [31]. They are promoted for their ability to support the creation of a shared meaning and collective identity as well as to facilitate social learning processes and the shaping of social practices $[23,24,31-34]$.

CoPs create opportunities as well as barriers for learning processes. With his framework, Wenger puts a community's formation at interplay with its ability to learn, shape practices and develop knowledge while recognising the reflexive relation to interactions with actors that are not part of that community. Applied to grassroots initiatives that stand in continuous tension between internal values and practices and the dominant rules and values of the existing regime outside the community, this approach offers a promising perspective for analysis.

Concerning the context-dependent nature of knowledge and its development in social grassroots initiatives many questions remain. On the one hand, there is a need for a better understanding of conditions and influencing factors that contribute to community building, maintenance and development. Thus, the first question concerns community dynamics. How do community dynamics turn individual perspectives into a joint endeavour?

On the other hand, making conditions around learning processes more explicit can inform decisions concerning interactions with other organisations and actors across borders. Hence, the second question deals with the community's connection to external actors. How does a community and its respective relation to its members affect the interactions with external actors?

Confronting these questions could help to more systemically illuminate dynamics that are essential in the creation, development, maintenance and diffusion of knowledge and practices.

In this paper, we examine how the CoP framework can inform the analysis of the potential of learning processes, drawing on an exploratory qualitative case study of the German permaculture community. Using the CoP approach to harvest more detailed insights into grassroots initiatives, aspects of the community's self-organisation were investigated. Special attention was directed to 
embedded learning processes, the relation of the individual to the community as well as to conditions at the interaction interfaces to external actors.

The outline of this article is as follows. We start with a background section where we outline findings and knowledge gaps in the literature from sustainability sciences, with the focus on transitions and resilience research concerning grassroots innovations. We then present permaculture as a prominent grassroots movement that promotes sustainability. Correspondingly, we argue how the $\mathrm{CoP}$ framework can contribute to addressing the identified gaps. Subsequently, the methodology is presented, drawing on 12 semi-structured interviews with German permaculture teachers. Then, the findings of the case study are presented, assessing whether the German permaculture community can be related to characteristics of a CoP. Also, some meaningful features of the community's configuration at the time of the investigation are described. This is followed by a discussion of both the results and the framework's overall meaning for sustainability science, including implications for further research.

\section{Background and Theoretical Context}

In this section, relevant aspects from the ongoing debate in the literature are highlighted. Then, the conceptual framework is presented as it is applied in this paper. Finally, permaculture as a prominent grassroots movement is introduced.

\subsection{Transformative Change through Grassroots Initiatives}

Grassroots initiatives facilitate the emergence of new ideas and practices and support the creation of more connected and locally embedded structures $[11,35]$. This, in turn, is seen as an important driver of sustainable development $[36,37]$. However, the lock-in effects through path dependency nested in the conventional ways of thinking and the perception of what is possible $[4,8,11,38,39]$ as well as in the practices and infrastructures that are reinforced and reproduced under the current socio-technical system $[28,40-42]$ inherently impede the diffusion of alternative values and practices developed in grassroots initiatives $[38,43,44]$.

Investigating dynamics on multiple levels, scholars started to raise questions about the impacts and factors of success and failure of grassroots initiatives and their networks [19,20,24,38,43,45-47], their organisation and community dynamics $[12,35,48-50]$, as well as concerning the psychological factors of individual engagement [51,52].

Assessing factors for success or failure of grassroots innovations in an international study of initiatives from the Transition Town Movement, Feola and Nunes have highlighted the relevance of both community internal as well as external factors and especially each initiative's ability to contextually relate to these [43]. This calls for more adaptable analytical concepts that are able to capture a community dynamics with respect to the specific context.

Moreover, theories of learning suggest that learning processes are especially promising where differences and a "generative tension" arise [29]. However, insularity and an inward-looking perspective present barriers that have not yet been overcome [12,22-24].

Overall, despite growing scholarly attention, a gap remains between the organisational dimension of the community where knowledge and practices are developed, appropriated and potentially diffused across boundaries on the one hand and the dimension of individual agency on the other hand. Clearly, in order to account for dynamics before practices become part of the prevalent rule-set, analytical means are required that allow a closer look at the emergence and diffusion of practices and knowledge as well as respective facilitating factors.

We argue that the CoP framework can be of value to more systemically link the individual to the community level, acknowledging factors that make up a community's effectiveness and shedding more light on factors contributing to the diffusion of knowledge and practices and overall capacities for sustainable development. 


\subsection{Social Learning Processes in Communities of Practice}

Even though the contexts, foci and conceptualisations differ across disciplines, it is uncontested that for profound changes to happen, social learning processes are essential [53-57]. What makes a closer examination of social learning processes relevant for processes of transformation towards sustainability is its context-dependent nature or situatedness [28] as well its relation to processes of meaning-making and the shaping of different values and practices [14,58].

Looking into theory of organisational learning, Etienne Wenger [28-30] developed a framework on learning dynamics building on the idea of situated learning. Coming from the discipline of knowledge management and organisational learning, Wenger [29] explicitly assumes a social perspective in order to describe the process of learning. This is motivated by the assumption that learning processes are inherently social activities in a network (formal or informal, face-to-face or virtual) and as such a function of the contextual characteristics.

The situatedness of learning conceives learning processes as socially shaped formal and informal processes that define a group's ability to draw on relevant knowledge in order to solve complex problems [59,60]. At the same time, it acknowledges the development of social capital $[33,61,62]$. Wenger's intentions were both to generate insights for design and analysis of organisations and to "guide the inquiry of the researcher as well as the action of the practitioner: what to pay attention to, how to give direction to our initiatives and where to focus our efforts" [29] (p. 226). Thus, it is of use both as a descriptive and proscriptive tool for groups of people with a joint endeavour $[31,33,34]$. As a consequence, it can be relevant to the study of grassroots initiatives in sustainability transitions [24]. By using the suggested structural elements $\mathrm{CoP}$, boundary processes and identity nested in social learning systems, key factors considering group-internal processes and boundary processes to external actors are defined which influence the overall effectiveness of a given CoP.

\subsection{Conceptual Framework}

\subsubsection{Community of Practice}

Simply put, a CoP represents a group of individuals with shared interests and problems related to a specific topic. By mutual interactions and knowledge exchange, they develop and deepen expertise in the respective field over time. Criteria were based on what Wenger [29] emphasises as decisive factors in the development of a CoP. "Definition and meaning" generally delineate what the interviewees understand under the concept of permaculture, while "Competences, shared repertoire and relevant knowledge" investigate what the community members consider as relevant knowledge, skills and routines. "Learning energy" describes where the focus of learning processes in the community lies. "Network characteristics" more specifically address aspects of community's organisation. Under "Social capital and trust" it is investigated, what the community means to the interviewees.

\subsubsection{Boundary Processes}

Boundary processes refer to the interactions in which the competences and practices of the community members commonly encounter different territory. According to Wenger [29], special learning potential exists where competence and experience are in close tension. As a result, the nature of boundary processes of the community in question - the conditions under which members engage with non-members-play a prominent role. While "Translation" relates to instances in which members actively seek to translate the idea of permaculture across their community's boundary, "Alignment" deals with the extent to which common interests can be found between the different parties involved.

\subsubsection{Identity}

Talking of social learning as an "act of belonging", necessarily, the identity is a key to element of the learning process [29] (p. 238). The perception of oneself and of the communities one belongs to defines what is considered to be meaningful, what is needed (or not) to be understood and which 
information is shared. With one's identity one can create boundaries or bridges. While "Home base" investigates the relationship to the CoP, "Multi-membership" concerns the members' engagement in and connection to other groups as well as the individuals' personal networks. Figure 1 depicts the structural elements and their respective analytical focal points as applied in this study.

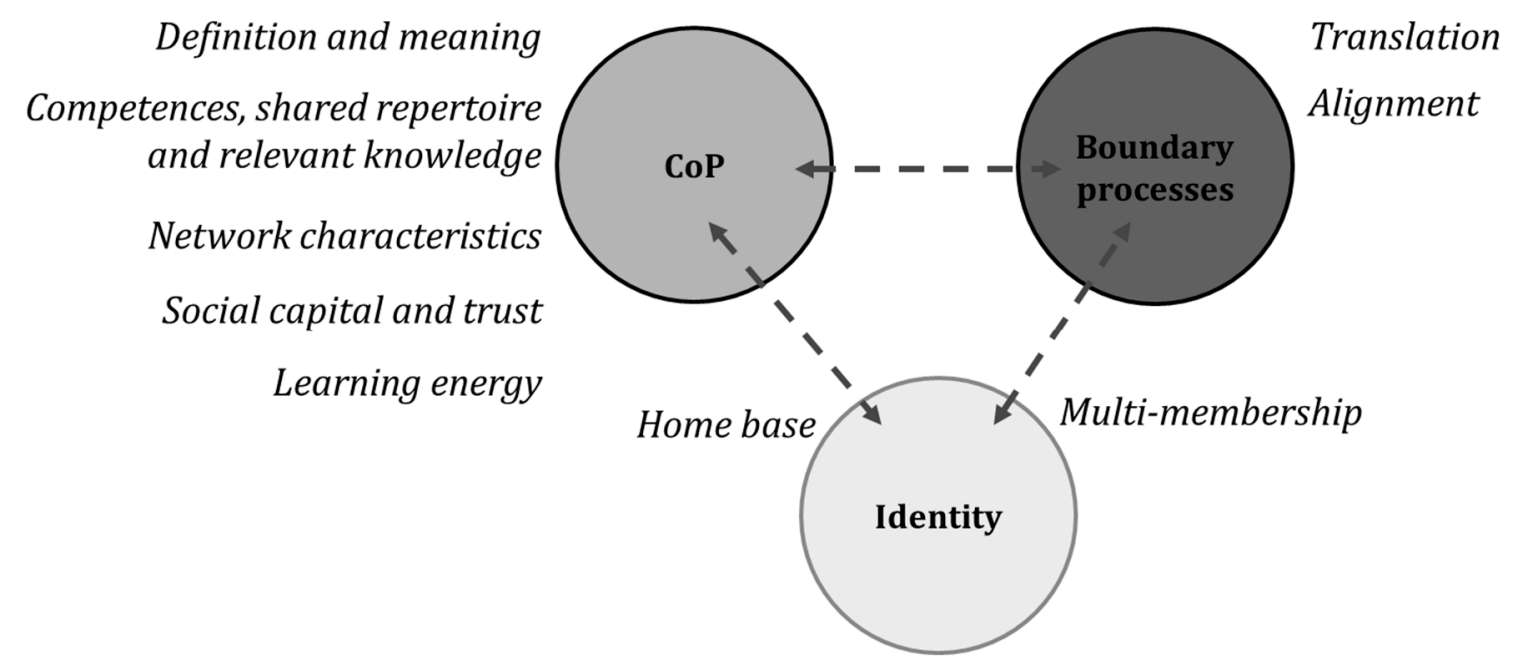

Figure 1. Structural elements and some key analytical criteria according to Wenger [29].

\subsubsection{Permaculture}

Permaculture as a portmanteau of "permanent agriculture" originated in Australia at the end of the 1970s [63]. Most commonly, permaculture is seen in relation to agro-ecological farming and the design of regenerative, closed-loop systems, where it first originated from. However, it has evolved to a broader application in practice as an ecologically informed holistic planning and design system for complex systems $[49,63,64]$ that can be applied to ecosystems as well as social systems [65]. Although it is difficult to give a concise definition of permaculture it can be roughly outlined in terms of four interrelated characteristics $[63,66]$. First, as a worldview it underscores the potential of synergistic effects on human well-being and ecosystem health that are realised when holistic, ecologically informed design and management practices are applied. Simultaneously, it offers a model of change that empowers people by stressing the individuals' and local communities' ability to take direct and concrete action [49]. Second, as a design system permaculture draws on ecological and systems-thinking principles, offering strategies and tools for analysis and selection criteria for appropriate practices sensitive to the respective site conditions and goals [49]. Third, since many tools and practices are adapted from other disciplines, Ferguson and Lovell [49] suggest that permaculture is best described as a best practices framework modelling ecological systems aiming to optimise systems. Finally, people with an interest in permaculture engaging in informal self-organised networks loosely form a movement on the regional, national and international level. Due to the preference of small-scale solutions and individual responsibility, a flat network structure emerged, less institutionalised and organised than other movements [49]. In fact, Bill Mollison, co-originator of permaculture, stated that in order to change the world, the multiplication of individual initiatives which cooperated with each other would suffice [66].

One commonality is the Permaculture Design certificate which is seen "as the heart of permaculture education" [67] (p. 16). It is given to people that participated in a 72-hours Permaculture Design Course (PDC), which follows a broad but structured curriculum and is internationally recognised among permaculture practitioners. In 2017, there were approximately 2500 permaculture projects listed in 120 countries and it is estimated that the number of people that took part in a PDC amounts to between 100,000 and 500,000 people worldwide [66]. The European Network for Community-Led Initiatives on Climate Change and Sustainability (ECOLISE) estimates that worldwide 
up to 3 million practitioners engage in permaculture with the support of around 280 strategic networking organisations [68]. In 2015, the UK Permaculture Association funded the Permaculture International Research Network (PIRN), by now counting 700 researchers from 60 countries. With this, the network is also establishing its own scientific body, documenting and critically reflecting on the established knowledge [64].

Even though permaculture originated from an academic context in Australia and became a popular, internationally distributed scheme, scholarly research projects with and on permaculture are only developing for some years. Several reasons account for the isolation of permaculture from the contemporary scientific community. A common criticism concerned its misalignment with contemporary scientific perspectives, such as a suggested oversimplification of the complexity of socio-ecological processes as well as lacking assessments and evidence of the impacts of permaculture design practices [63]. Furthermore, the absence of a clear description may have hindered a more systematic and rigorous discussion [63].

Explicitly working against prevalent paradigms while diffusing from the bottom-up across the world; however, it offers an interesting case to study as a CoP.

\section{Methodology}

\subsection{Researcher's Background}

The researcher performing the interviews was acquainted with permaculture due to her former active participation in projects drawing on permaculture. She had engaged in a six-week voluntary work in a community in India that made use of permaculture principles in agro-forestry and community design. Furthermore, she came in touch with permaculture teachers as a part of a study project. These experiences provided a basic familiarity and an understanding of the context in which permaculture is applied.

\subsection{Methods}

The investigation started with literature reviews on both the theoretical background as well as on the present situation of the permaculture network in Germany. Theory on social learning systems $[23,28-30,69]$ informed the formulation of the conceptual and analytical frameworks. Due to the nature of the relevant information, time horizon, resources and scope, a qualitative research approach was chosen.

Furthermore, since this research was primarily about the personal motivations, knowledge exchange and experiences of permaculture practitioners a case study approach was selected as an appropriate analytical means to acquire the necessary in-depths information [70]. Semi-structured interviews were selected as an effective method to retrieve the relevant insights on perspectives, organisational aspects as well as on processes of knowledge exchange within the limited resources and time of this research. As the German permaculture network decentrally spreads across the country, this proved to be an effective method to acquire in-depth information on the community dynamics, individual perspectives and to get an overview of the ongoing boundary processes.

A snapshot analysis was chosen [71] to investigate the state and processes of the permaculture community in Germany in 2016. After the framework had been sufficiently defined, an interview guideline for the empirical analysis was designed. For reasons of practicality and representativeness, the analysis primarily focussed on the network of trained permaculture teachers, assuming that they were informed key actors in the shaping and diffusion of permaculture knowledge and practices.

Twelve interviews have been performed in April and May 2016. Interviewees were teachers from the biggest body of education on permaculture in Germany, the Permakultur Akademie (PKA). First, interviewees were chosen based on convenience sampling through an online search for permaculture teachers in practice. After the interviews were started, snowball sampling was used, asking the interviewees to recommend permaculture teachers that were working with a different focal point. 
It was regarded as desirable to yield a diverse overview on possible occupations and connections of the permaculture community in Germany. The interviews were in German, relating to information on the interviewees':

- $\quad$ age and employment status

- motivation to engage in permaculture and the network

- understanding of related practices and knowledge

- position and role within the permaculture network

The transcripts from the semi-structured interviews were coded in a deductive way by a priori clustering based on the analytical framework [72]. Only after that certain quotes were translated. Table 1 gives an overview on the respective analytical focal points and key concerns for the different elements. The interview guideline can be found in the corresponding Master thesis [73].

Table 1. Key concerns for the analysis of the three structural elements.

\begin{tabular}{|c|c|c|}
\hline Structural Element & Focal Point & Key Concerns \\
\hline \multirow{6}{*}{$\begin{array}{l}\text { Community of } \\
\text { practice }\end{array}$} & Background & $\begin{array}{l}\text { What was the historic development of the PKI and PKA? } \\
\text { How many members are there? }\end{array}$ \\
\hline & Definition and meaning & $\begin{array}{l}\text { What is the definition of permaculture? } \\
\text { What is the value in permaculture and the meaning to } \\
\text { the individual? }\end{array}$ \\
\hline & $\begin{array}{l}\text { Competences, shared } \\
\text { repertoire and relevant } \\
\text { knowledge }\end{array}$ & $\begin{array}{c}\text { What competences are considered as key to practicing } \\
\text { permaculture? } \\
\text { What are important sources of knowledge? }\end{array}$ \\
\hline & Learning energy & $\begin{array}{l}\text { Where does learning take place in the network? } \\
\text { What are current key directions for the development of } \\
\text { the network? }\end{array}$ \\
\hline & Network characteristics & $\begin{array}{l}\text { Which functions does the network fulfil in general? } \\
\text { How does the network support engagement? }\end{array}$ \\
\hline & Social capital and trust & $\begin{array}{l}\text { Which meaning does the network of permaculture } \\
\text { practitioner have for participation? } \\
\text { Is it important for the individual's engagement? }\end{array}$ \\
\hline \multirow{2}{*}{$\begin{array}{l}\text { Boundary } \\
\text { processes }\end{array}$} & Translation & $\begin{array}{l}\text { What activities happen, are people looking for work } \\
\text { with people external to the network? }\end{array}$ \\
\hline & Alignment & $\begin{array}{l}\text { Is there support on a network-level for activities at the } \\
\text { network's boundaries? }\end{array}$ \\
\hline \multirow[b]{2}{*}{ Identity } & Home base & What is the meaning of being part of the network? \\
\hline & Multi-membership & $\begin{array}{c}\text { In which other networks are people engaging? } \\
\text { Can they combine their participation in different } \\
\text { networks consistently? }\end{array}$ \\
\hline
\end{tabular}

\subsection{Data Validity and Limitations}

As we drew on a relatively small number of interviews several limitations that restrict generalisations of the results need to be recognised. We applied the CoP framework with the purpose to freely explore characteristics that account for relevant processes of knowledge creation and sharing. Correspondingly, we would like to emphasise that neither the sample size of twelve interviews nor the selection process of interviewees claim to be exhaustive. Having interviewed twelve of overall 26 teachers, the results can offer some insights on Germany's biggest permaculture association. Furthermore, the data indicates whether the organisation meets characteristics found in CoPs and how the different characteristics defined by the CoP framework interrelate in this particular case. However, the results neither represent a full picture nor can they validate the $\mathrm{CoP}$ approach in general. Moreover, it is important to note that the interviewees' network represented only a small part of the overall 
permaculture network comprising many course participants and permaculture practitioners. Overall, given the restricted time frame and resources, this investigation rather aimed to provide an overview of different motivations, perspectives and interactions and explore whether the $\mathrm{CoP}$ framework can offer a valuable analytical lens to closer examine grassroots initiatives.

\subsection{Introduction to the Case: Background and Development of the German Permaculture Community}

Permaculture as a concept emerged in Germany in the early 1980s [74]. In 1982, the architects Declan and Margrit Kennedy invited Bill Mollison to Germany after having gotten to know him in Australia a year before [75]. In 1983, the Permakultur Institut e. V. (PKI) was founded as a non-profit organisation to provide a network and education on permaculture. Since 2003, the Permakultur Akademie (PKA) represents the PKI's "Zweckbetrieb", a special-purpose business, managing the training programme for permaculture designers in Germany. Both are part of several permaculture networks such as the European Permaculture network and ECOLISE [76].

The PKA is a platform for teachers who offer different formats of permaculture classes, ranging from short introductory courses to a three-year education programme which ends with the "diploma in applied permaculture". The PKA provides the curriculum and the accreditation of the German permaculture design diploma [76].

At the time of the interviews the PKA comprised 26 self-employed teachers, reaching a total of approximately 500 participants of different courses in 2016 (Permakultur Institut e. V, internal documents 2016). Of these, 80 were enrolled as students of the diploma of applied permaculture. The number of people relating to permaculture without being linked to an association was unknown.

In the past years, the training programme of the PKA was reorganised and in 2016 a new version of the course for the diploma of applied permaculture was introduced (Permakultur Institut e. V, internal communication 2017). Also the organisational structures of both the PKA and PKI were reorganised at the time of the interviews. With growing members and tasks of the network, the active participants in the two organisations decided for a restructuring which was loosely based on the concept of sociocracy, allowing for coordinating circles with different key tasks and responsibilities.

In the limited scope of this article, it is not possible to provide an exhaustive overview of the insights that emerged during the interviews. Instead, we focus on the analysis of some key characteristics of the $\mathrm{CoP}$ and the dynamics of learning processes. For more detailed information we refer to Ulbrich [73].

\section{Findings}

In the following, the results concerning the characteristics that emerged during the interviews are presented in line with the three structural elements.

Starting with the CoP dimension, it is illuminated under which conditions a shared body of knowledge and practices was shaped by the practitioners. The boundary processes dimension illustrates the connections to actors outside the permaculture community, investigating both the challenges and the potential for translation of knowledge and cooperation. Finally, the identity dimension addresses the relationship between how the CoP affected the individual and how this shaped boundary processes and vice versa. Translated excerpted quotes from the interviews where used in order to illustrate the findings.

\subsection{The Community of Practice}

To explore the character of the network of permaculture teachers as a potential CoP, it was investigated how the interviewees participated in and related to network processes. The key questions were what gave meaning to their participation and what gave their learning processes a common direction. We start by describing the interviewees' definitions and the meaning they assigned to permaculture and further elaborate on which competences and relevant knowledge they deemed important for being a permaculture practitioner. Then, we look at some network characteristics and 
the main concerns of learning efforts in the organisation. We end with investigating the importance of social capital and trust in the network.

\subsubsection{Definition and Meaning}

There exist many definitions of permaculture. The German permaculture teachers related to permaculture in similar ways as Ferguson and Lovell described [63]. Supporting the worldview characteristics, the ethical basis aligned the teachers on a common ground. They directly linked human activities to the quality of life on earth, with the objective to value and take responsibility for the planet. This was expressed by some interviewees as a kind of philosophy or attitude.

The systemic perspective and predominant focus on functions and relationships when looking for solutions were strongly perceivable in the interviewees' reasoning. The generalist point of view also found expression in the understanding of what is perceived as being valuable and legitimate. If, for instance, the agricultural yield of a crop was kept at a certain level through a permaculture design that supported small-scale integrated farming rather than profit maximisation, other yields instead such as soil restoration, social equity and education practices were taken into accounting as a yield. The appreciation of multi-functionality surfaced as a core aspect of permaculture practice.

In particular, the notion of a wide system boundary and the systemic perspective was mentioned in the interviews as a core feature of permaculture.

“[ ... ] arriving at permaculture has a lot to do with challenging current paradigms.

The own pathway, the own situation of life, our societal system. This is nearly a prerequisite. [ ... ] if you take permaculture serious you and also what you learn and try out, then it leads to changing the perspective onto the world."

For others, permaculture was predominantly the systemic design framework and a set of practices that supported systems thinking and design. All interviewees stressed the importance to distinguish permaculture as a framework that consists mainly of principles for orientation from the toolset it subsequently used, comprising analytical, technical and social methods.

Another important aspect was the holistic character of permaculture that linked systemic analysis to concrete directions for actions. This made it meaningful to the interviewees.

"And it is multi-layered. We can use our head, our heart and our hands, it is something practical, something philosophical and something between human beings. It is holistic, that's the attraction"

\subsubsection{Competences, Shared Repertoire and Relevant Knowledge}

Competences are knowledge and routines that the interviewees share through their participation in the CoP. The three ethics united the interviewees and provided a sufficient basis for collaborative work. Still, this seemed to leave enough freedom to practice permaculture according to individual preferences. In terms of knowledge sources, different media were mentioned. The permaculture design principles as well as a set of ecosystem criteria were frequently referred to as important means for orientation. Books from Bill Mollison and David Holmgren, the founders of permaculture, were referenced but were not the only sources of knowledge. Rather, the interviewees stressed that they drew knowledge from various sources. Among others, literature, the Internet and their personal network were named as important sources of information. There were several journals and many books that covered permaculture as a topic. Oya, a German journal on alternative ways of living, even had an own section on permaculture.

Many interviewees expressed that the theoretical framework was informing their every-day practices, for instance as an analytical tool and a base for decision making. Occasionally, an interviewee also drew on principles of permaculture design to illustrate a line of reasoning. As an example, in order to emphasise the need for cooperation the interviewees commonly referred to the permaculture principles "integrate rather than segregate" and "use the edges". 
In general, the ability to practically apply permaculture by drawing on the ethics and principles in different contexts seemed to have a particularly empowering effect for several interviewees.

Also the language many interviewees used displayed a common communication culture. Often, they drew on words with analogies in nature such as "polyculture" to describe having different jobs at the same time; "cultivate" or "seed" meaning the development and transmission of mind-set and practices. Also, interviewees explicitly named the PKI and PKA as real-life experiments of applied social permaculture practices.

"Basically, the academy is our garden. Our social, economic garden."

Interviewees stated that seeing the relationships and cycles in ecosystems helped them to understand the consequences of certain actions, to see interrelations and to derive solutions from this understanding.

Everyone had an individual way to apply permaculture principles according to individual skills and interests. On the other hand, it required a strong individual initiative as a core competence and a disposition to individual and self-reliant learning. The interviewees agreed that practising permaculture related to a process. A part of the competence was to stay attentive, to observe and experiment, allowing mistakes in order to support learning processes.

"To see the necessity for one's actions, the competence to design and find solutions and to experiment. You do not have to know what is the right thing, but you have to dare to try it and to learn from it and to further develop it."

There was a commitment to reflection and learning as part of the interviewees' daily practice and teaching. Of special importance was learning to deal with uncertainties and constant change and flexibility. For this, the "inefficient" process of learning and experimenting was seen as inevitable:

"Because it needs skills, which people need to still learn themselves [...]. And there you have to try a lot and experiment. And if you do not have the chance to get support, e. g. through foundations, many cannot afford it to change. It needs a lot of bravery and young people that are not yet stuck in responsibility."

Another important aspect was the will for cooperation instead of competition.

\subsubsection{Network Characteristics}

The network of the PKA and PKI was decentrally organised and widely spread across Germany. The geographical distance between the members only made occasional meetings possible. The interviewees confirmed that the virtual communication processes worked well.

Investigating the composition of the members, the network was described as diverse but homogeneous at the same time. People came from many different backgrounds but displayed similar attitudes.

Concerning the informal community of people that were not associated with the PKI, several interviewees named the diversity of values and approaches as a challenge. The integrative character that was apparent for the interviewees within the organised network of the PKI was perceived only to a lesser extent.

\subsubsection{Learning Energy}

At the time of the interviews in spring 2016, dealing with growing interest by students was an ongoing learning process of the PKI. In terms of self-organisation and education, the community was creating a suitable organisational form with different properties compared to common hierarchical structures in the German context. Sub-communities as well as organisational circles were slowly emerging. Here, the ethics, design principles and tools played a vital role in the development process. 
"We try to provide a structure and simultaneously we notice that it needs a lot of free space. And this balancing act to develop a structure which gives free space, that is really exciting."

One interviewee raised the concern that the education programme of the PKA might only function as a "Durchlauferhitzer", comparing it to a water heater that boils water giving it away immediately. Using this analogy the interviewee illustrated fears that the PKA invested energy in education but did not accumulate the energy because participants would not stay connected to the community after their training. This inhibited the growth of a common body of knowledge, experience and functioning projects. One indicator for this was seen in the lacking data base of projects and learning outcomes from former projects. Some interviewees were concerned that the absence of visible examples of permaculture application in Germany as compared to the international permaculture movement was a sign of limited progress. Others said that it simply needed time since the internal organisation was more pressing. Being busy with dealing with the internal growth, no coordination of broader strategies concerning the development of the community was discussed.

Everyone was responsible for their own learning progress and participation. This restricted the generation of a shared body of knowledge. Likewise, the learning energy committed towards external issues was not pronounced. At the time of the interviews, connecting to external fields and expert knowledge was up to personal initiative. As a reason, the lack in capacity and initiative was stated which would be required to organise and coordinate such events.

\subsubsection{Social Capital and Trust}

Social capital and trust were named as important features for the interviewees' participation in the network. Interviewees valued the common understanding as well as the diversity of ideas and skills. The network-internal contacts supported them through open knowledge exchange. Some especially emphasised that working together on the base of the permaculture framework within the PKA and PKI and being able to contribute to the organisation's development was meaningful to them.

\subsection{Boundary Processes}

Looking at features of boundary spanning specifically through translation it was explored whether the interviewees' actively worked at the boundaries of the organisation. Furthermore, the criterion of alignment investigated which conditions supported and challenged boundary work.

\subsubsection{Translation}

Both in their private and professional life, the interviewees were regularly in contact with people that did not relate to permaculture in any way. Translating the comprehensive framework of permaculture, the recognition of wide system boundaries and the three ethics often proved difficult due to the topic's complexity. Different coping strategies came up in the interviews. For instance, often, the use of other terms instead of the general framing as permaculture seemed to better resonate. The recently founded Agroforst Kampagne, agro-forestry campaign, in cooperation of some permaculture designers with a non-profit organisation was an attempt to address the agro-ecological context and to become recognised by prospective partners.

As a general obstacle many interviewees mentioned some people's superficial understanding of permaculture, taking the mere presence of raised flower beds and herb spirals for permaculture. Communicating the diversity of possible uses of permaculture and the complexity of underlying relationships was a key challenge. Some interviewees raised a wish for more visible examples in Germany that people can simply experience.

Directly addressing the task to span boundaries, several of the interviewees stated that they tried to extend the scope in which permaculture found application. Some interviewees looked for connections to like-minded movements, such as cooperation with people from environmental and wilderness education. One interviewee had an editorial position on the topic of permaculture in a magazine. 
Some interviewees mentioned their participation in activities on degrowth, some emphasised their connection to Demeter farmers and herb experts. Other interviewees were keener on extending the margins further away from the community's mind-set.

"Where there is no contact, nothing happens and attitudes solidify. [ ... ] But there lies a lot of potential in permaculture since there are many constructive methods in conflict resolution. In this regard we cannot let this potential unused. We cannot just limit ourselves based on the argument that it costs efforts."

In 2016, translating permaculture into context for others, was not strategically approached or coordinated on a network level. Some interviewees worked with organisations from education and pedagogics on volunteering programmes, community gardens and projects with refugees. Design work with farmers and other private clients was another service that was offered by a designer.

Even though bridging boundaries was challenging, the interviewees emphasised its importance for the further development and dissemination of permaculture.

"And that is like constantly doing the splits. You need to go where people live and how the mainstream functions."

\subsubsection{Alignment}

Alignment explores in which contexts and to which extend it was possible to find common meeting points at boundaries. An emerging professionalisation and differentiation was a good indication of the efforts to translate knowledge at borders. This was possible, because single permaculture practitioners made the effort to integrate the permaculture framework in their profession. However, it was not easy to appropriately translate these functions into a conventional context. Accordingly, a certain confidence and spirit was required to negotiate suitable solutions. This depended on the knowledge of the respective discipline and the identification of windows of opportunity, in which new ideas are welcome.

"[ ... ] Win-win situations. [ ... ] But for this you need to know your counterpart and you need to look for what this person needs. And you can only really do that if you are from this context. For instance, with the academic field it maybe only works when you are from academia yourself. [ ... ] I think you need people that want to be pioneers in this field and look for win-win situations and manage it."

Knowing how to create win-win situations and "the rules of the game" was deemed essential to create these linkages. Interviewees also mentioned that links could be created through direct contact to people in strategic positions who took actions beyond their usual tasks.

On both the individual and community level connections existed to partner networks with similar attitudes such as the Global Ecovillage Network, degrowth, Transition Towns and Community Supported Agricultures.

Connections to more conventional organisations such as universities or municipalities arose in dependence to personal contacts from permaculture designers. Having different approaches made cooperation with established institutions, as it was time and resource intensive. Formal procedures were often slow and not easily accessible. Establishing a project that had a sufficient time line and whose finance was guaranteed was a common challenge.

"These are mills that grind slowly, and it takes a lot of time. But I believe that currently some things change and that also people in the ministries are more open. [ ... ] But it also depends on the engagement and ideas of single actors, which are a bit more concerned and do not only do their job." 


\subsection{Identity}

Looking at home base, insights on the individual relation to the community were collected. Subsequently, multi-membership addressed the interviewees' engagement in groups not familiar with the concept of permaculture and how they dealt with respective challenges.

\subsubsection{Home Base}

Using the framework of permaculture in a personally meaningful way and getting to know like-minded people in the community motivated the interviewees to engage. These social ties were clearly perceivable in the network of the interviewees and reinforced their motivation to engage.

"Yes, indeed, this encouragement. That I know "we are many and we are everywhere."

Because sometimes you sit there all alone and do your work."

A prerequisite was that individuals were self-reliantly able to apply the permaculture framework and to find effective ways to express themselves. Through the very practical and personal integration of permaculture practices, each member acted self-responsibly. It was clear that a combination of strong individual curiosity and community support guided members. It also enabled them to further differentiate their skills and profile.

"I think if one is creative, one also creates a space in which one can do something. And there it also needs a kind of entrepreneurial spirit. I do not know whether everyone has that or whether one develops it automatically when one engages in permaculture because it does release a lot of creativity."

\subsubsection{Multi-Membership}

Several interviewees actually went through a personal state in which they felt torn between their own ideals and being part of a system whose values they did not support. However, some interviewees began to feel more accepted than in previous years. The personal conviction and a new public perception motivated the interviewees to further disseminate the permaculture framework, although it was not easy to find a paid job related to permaculture. Common challenges were questions of time, resources and priorities. Additionally, difficulties that came with self-employment and the financial burden were important and challenging factors. Again, successful multi-membership depended on the individuals' competences and entrepreneurial skills to integrate the framework with their own background. Looking at the interviewees' employment profile it was visible that they usually had a diverse set of streams, a "polyculture", of incomes, not always related to permaculture. Several interviewees mentioned the challenge to self-organise a steady flow of income that allowed focussing on their profession as a permaculture teacher.

This section may be divided by subheadings. It should provide a concise and precise description of the experimental results, their interpretation as well as the experimental conclusions that can be drawn.

\section{Discussion}

\subsection{Community of Practice}

Based on the results from the interviews with teachers associated with the biggest organisation on permaculture in Germany, we now discuss the meaning of CoPs for theoretical and conceptual orientation for the permaculture community and its relation to social innovation. Afterwards, we give an outlook on using CoPs as a tool for self-analysis in order to inform action in the study of sustainability transitions in general.

The network of teachers in 2016 certainly displayed characteristics of a CoP, with both strong core practices and active boundary processes. The organisational structures of the PKI and PKA themselves 
represent real-life experiments and are a direct result of the application of social permaculture design. Table 2 displays a summary of the results derived from the different criteria of the three structural elements.

Table 2. Summary of the results evaluating the three structural elements.

\begin{tabular}{|c|c|}
\hline Structural Element & Results \\
\hline Community of practice & $\begin{array}{c}\text { Shared repertoire through three ethics, design principles and ecosystem criteria, } \\
\text { shared language } \\
\text { Adaptability of permaculture as a framework allowed individuals to engage with } \\
\text { their own skills } \\
\text { Depending on strong individual initiative } \\
\text { Cooperation, individual learning and experimenting belonged to the core principles } \\
\text { Trust and understanding in the community were key reasons for participation } \\
\text { Internal growth and increasing member numbers were apparent } \\
\text { Organisational learning was an integral part of the community, restructuring the } \\
\text { community as needed } \\
\text { No designated capacity to accumulate knowledge beyond the individual } \\
\text { level perceivable } \\
\text { Absence of show cases in Germany }\end{array}$ \\
\hline Boundary processes & $\begin{array}{l}\text { Complexity of permaculture makes it difficult to communicate } \\
\text { Slowly establishing connections to education institutions and municipalities, } \\
\text { sometimes the term permaculture is not used } \\
\text { Good connections to like-minded movements and disciplines such as wilderness } \\
\text { education, Global Ecovillage Network, community-supported agriculture and } \\
\text { Transition Towns }\end{array}$ \\
\hline $\begin{array}{c}\text { Identity } \\
\text { (Home base) }\end{array}$ & $\begin{array}{l}\text { Strong connection between knowledge and practice: the framework of permaculture } \\
\text { was perceived as personally meaningful and empowering for the individual } \\
\text { Open for individuals to express and integrate their own visions in the CoP } \\
\text { Shared understanding, knowledge exchange and trust in in PKA and PKI reinforced } \\
\text { motivation to engage in the CoP }\end{array}$ \\
\hline $\begin{array}{c}\text { Identity } \\
\text { (Multi-membership) }\end{array}$ & $\begin{array}{l}\text { General perception of permaculture by general public changed positively which } \\
\text { reinforced the participants' engagement } \\
\text { Challenge to embed permaculture in a professional environment, which required an } \\
\text { entrepreneurial attitude }\end{array}$ \\
\hline
\end{tabular}

At the time of the interviews, boundary processes depended on the initiative of key individuals rather than being addressed on a community-level. Difficulties due to lacking recognition as well as strong dependence on social capital and fortunate circumstances were visible. Through these factors, only a limited public perception of the German permaculture community existed. Certainly, the strength of permaculture to be of use in many different situations and under different conditions also became its biggest challenge. Communicating the meaning of permaculture to others without examples that allow for simple experiences of the underlying complexity proved to be difficult.

Nonetheless, slowly connections to other fields were emerging as was apparent in some projects of permaculture teachers with universities, other education institutions and municipalities. At the same time, the permaculture community steadily grew.

The analysis showed that the community was mainly concerned with internal, qualitative growth in order to accommodate the quantitative growth of members. This limited the capacity to extend the boundaries and to strategically translate the concept to people without an inherent interest in permaculture in the first place.

The analytical dimension of home base further illuminated the deep connection between knowledge and practice of permaculture. The interviewees displayed a strong relation between their individual identities and the $\mathrm{CoP}$ through a shared understanding, common interests a shared culture.

Enabling action and participation of individual members independent from the environment they find themselves speaks for the strength of the CoP. Drawing on the permaculture framework helped 
the interviewees to creatively embed values that stand in contradiction to the dominant paradigm in their private life and professional career. This corresponds to what Maschkowski et al. investigated under the concept of salutogenesis and sense of coherence [51]. It states that empowerment can be achieved through a comprehensive understanding, meaningful engagement and manageable steps of action embedded in a community. The interviewees confirm that permaculture, despite the decentral network, provides a comprehensive framework that informs actions and is able to maintain a lively community. Both together created a feeling of empowerment. Engagement and related positive experiences reinforced the decision to participate in the community. This aspect of empowerment is a significant criteria for social innovation [77].

Differentiating analytically between the organisational level of the $\mathrm{CoP}$ and the identity links the community level to the individual's mind-set and values. A shared body of values and culture was reproduced based on strong core values and ethics, a shared language and the opportunity to engage with individual capacities. Likewise, the shared repertoire such as the permaculture principles gave an orientation and supported trust.

At the same time, the individual served as the bridge between the expertise and practices embedded in a CoP and boundary processes. An interesting question would be how and whether the community could better support participants in their jobs associated with permaculture. The ability of a $\mathrm{CoP}$ to offer both a strong home base while supporting successful multi-membership are important factors to keep members engaged in a CoP.

In conjunction with this, an interesting component for further exploration concerns Wenger's criteria trajectories of the individuals in the community. Trajectories show imaginable pathways for members in a community. With a variety of imaginable trajectories allows for a continuous but changing development and facilitates the connection between the individual and the CoP. Despite growing member numbers it proved difficult to keep people active over a longer time. Thinking how the imagination of trajectories can be facilitated in the future is one point upon which the network can further reflect upon.

Equally, it became clear that a growing community generated the need for guidance. Several interviewees stated that more concrete strategies that would be able to guide the growth were not perceivable at the time of the interviews. It might require appropriate enabling structures and more distinct collective goals in order to support the individual in a way that it can constructively contribute to the community development.

With this in mind, concerning the diversification of the permaculture network in Germany, an important question for the future is how the professional background of the members could be better made accessible for the network. Perceivable from the interviews was the dependence on individual initiative and ability to effectively exploit windows of opportunities.

Admittedly, the openness for individual initiative also indicated certain strengths. The flat network structures supported members to flexibly engage and bring in individual expertise. The re-structuring that resulted in a new organisational form, based on the very principles the interviewees brought in and valued, showed that organisational learning was an integral part of the community. Figure 2 illustrates some recommendations relating to the three structural elements. 


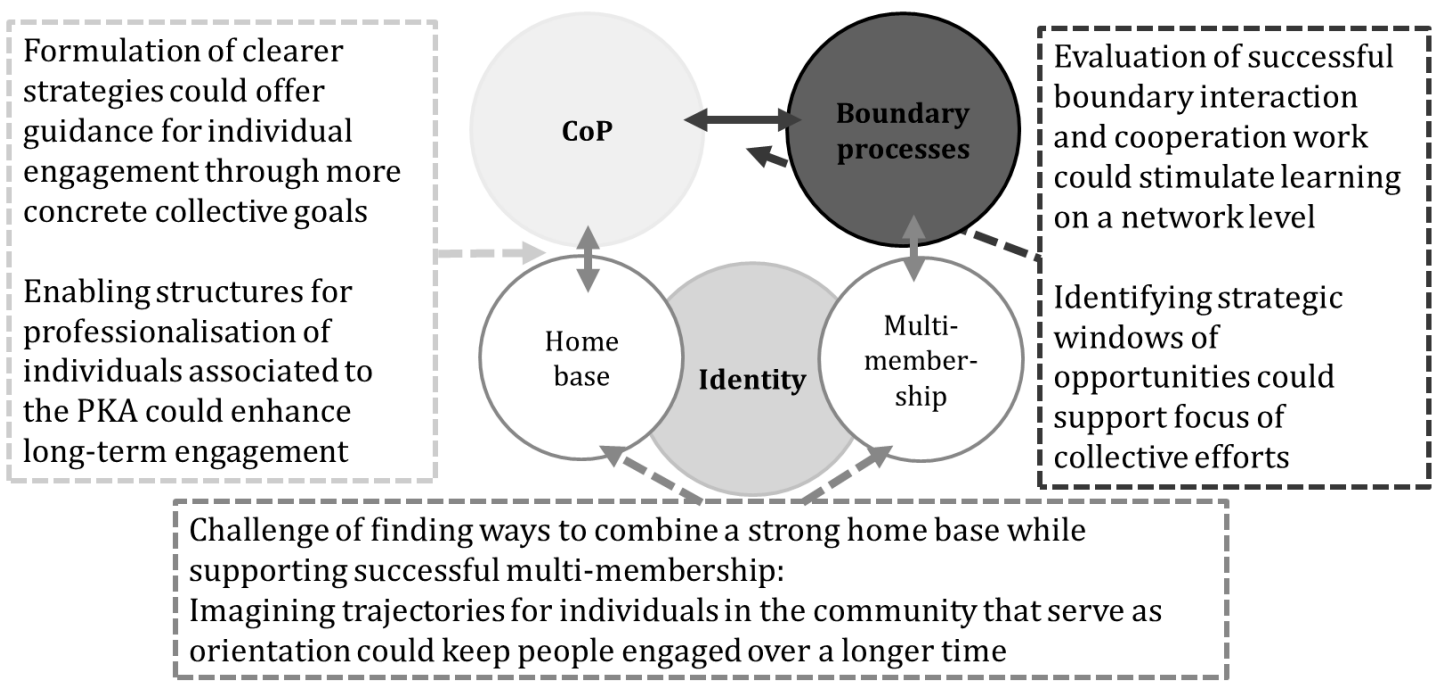

Figure 2. Recommendations from the insights on the three structural elements.

\subsection{Outlook}

At this point, we want to return to the outset of this paper. There is a certain urgency to facilitate transformative change of current institutions and social practices. By adapting the concept of CoPs to a distributed network of a grassroots initiative it was explored how community dynamics can be analysed in order to theoretically and practically inform about opportunities for learning and knowledge exchange. At the same time, it yielded in-depth information on the relationships of individuals to their communities.

Lately, serious efforts have been made to illuminate more dynamics of transformative social innovations $[19,27,77,78]$. The TRANSIT project on social transformative innovation [78] explicitly addresses communication and learning processes. In this respect, the CoP concept, focussing on learning dynamics contingent on identities and communities in social systems can support the understanding of the development and limitations of grassroots initiatives. How expectations are shaped and networks emerge fundamentally depends on respective communication processes and the ability to share knowledge and create opportunities for learning. CoPs, allowing for adaptable analysis of structures, individual agency and the reflexive effects on learning dynamics, represent a flexible framework that can inform actions, paying tribute to the inherently relational and reflexive nature of processes of change in socio-ecological systems.

This framework more rigorously depicts the various and complex aspects that support individuals in the creation of values and practices by help of a community. In the face of a conflicting environment, individual as well as collective factors, including both tacit and tangible aspects, virtual and real relations, help to embed practices and values in the daily life. Observing grassroots initiatives yields new insights on how the change and creation of practices and competences can be better recognised and supported, despite the current infrastructures and value system.

Not surprisingly, also non-governmental organisations themselves have already appropriated the concept of CoP to their needs. For instance, Transition Town has adopted the CoP as an organisational and operational framework at international levels with the goal to link municipalities, communities and decision-makers in the engagement with Transition-inspired approaches and through this catalyse the spread of Transition Town movement internationally [79]. The potential of this framework is to offer analytical insights while being of direct practical guidance for communities.

Although not having been an explicit part of the research goal, the data offered some fruitful information for the study of transformative social innovations. The empowerment of individuals in the community was reflected in two ways. First, the framework of permaculture in itself and the principles and practices, had a seemingly empowering impact on permaculture practitioners. These in 
turn helped to create governance structures that allowed members to work decentrally on different topics in a flat hierarchy and their own organisational form. Thus, by linking the individual and the collective perspective analytically, our ability to collectively profit from ideas and concepts thus far overlooked can be enhanced.

\subsection{Implications for Future Research}

Developing process theory is a key concern of research on social innovation. This points to a need to pay explicit attention to the geographical, political and social contexts of transformative social innovation initiatives [14,77]. Applying a CoP perspective in different cases could solidify the knowledge base on the participants' motivation and the different contexts in which CoPs develop as a joint endeavour. Furthermore, comparative studies between different countries can illuminate local and global links in movements. Likewise, extending the temporal scope could account for changing dynamics and patterns that occur with time.

In this respect, the permaculture community offers fruitful ground for further exploration. The difference between countries surfaced perceivably during the interviews. While permaculture farms and other showcases were present in several countries, visible projects in Germany were relatively rare. Investigating the conditions that contributed to these differences can help to illuminate common barriers, see which aspects work where and as a consequence better stimulate knowledge exchange in areas with similar conditions.

This analysis of complex interactions of a CoP and its boundaries was not able to cover all dimensions of relevant interactions and related factors. A question for debate is certainly the delineation of the network and the border of the respective $\mathrm{CoP}$ in question. In this research, the border was loosely drawn around the network of permaculture teachers connected through the organisational forms of the PKA and PKI. However, as permaculture is an umbrella for different interest groups, the $\mathrm{CoP}$ approach would benefit from various analytical degrees of engagement. In general, this could contribute to a more comprehensive understanding and differentiated analysis of grassroots initiatives with various forms of possible participation.

An aspect which was not addressed in this investigation was the role of power. Not only the grassroots initiatives in question need to make clear how exclusive they should be, but also collaborating institutions need to be aware that these initiatives have different characteristics and needs. One indication of this analysis is that discussion is needed on how the playing field on which grassroots and institutionalised bodies potentially meet can be effectively designed. Further exploring the CoP approach as a tool for self-analysis in transdisciplinary work could increase its immediate value in collaboration with initiatives developing from the bottom-up.

Finally, the lens of boundaries offered interesting insights into the social networks of the members. It directed attention to informal processes and less tangible factors. A known key barrier to the success of grassroots initiatives is their development on the margin of the established system. As a consequence of this incompatibility, research on the British permaculture community has concluded a certain tendency to insularity and exclusivity of the community $[23,24,49,66]$. However, the boundary dimensions also highlights processes more differentiated instead of focusing on the incompatibilities. For instance, while there were no connections to conventional farmers some interviewees maintained good contacts to and knowledge exchange with Demeter farmers. Here, investigations on the kind of boundary processes could substantiate the knowledge of conditions that make certain connections work more effectively than others. In this way, the concept of boundary processes can be developed to see where "generative tensions" [29] can be facilitated.

Author Contributions: The following work was completed by the respective contributing authors: Conceptualization, R.U. and C.P.-W.; Funding acquisition, C.P.-W.; Investigation, R.U.; Methodology, R.U.; Writing—original draft preparation, R.U.; Writing—review and editing, R.U. and C.P.-W.

Funding: We acknowledge support by Deutsche Forschungsgemeinschaft (DFG) and Open Access Publishing Fund of Osnabrück University. 
Acknowledgments: We are much obliged to the interviewees from the Permakultur Akademie and Permakultur Institut for their time and vital contributions by sharing their understanding. Furthermore, we would like to acknowledge Thomas Henfrey and appreciate his constructive feedback. Finally, we thank the anonymous reviewers and editors of Sustainability for their critical and helpful suggestions.

Conflicts of Interest: The authors declare no conflict of interest.

\section{References}

1. Kahneman, D. Thinking, fast and slow; Farrar, Straus and Giroux: New York, NY, USA, 2011.

2. Rockström, J.; Steffen, W.; Noone, K.; Lambin, E.; Lenton, T.M.; Scheffer, M.; Folke, C.; Schellnhuber, H.J.; De Wit, C.A.; Hughes, T.; et al. Planetary Boundaries: Exploring the Safe Operating Space for Humanity. Ecol. Soc. 2009, 14. [CrossRef]

3. Leach, M.; Rockström, J.; Raskin, P.; Scoones, I.; Stirling, A.C.; Smith, A.; Thompson, J.; Millstone, E.; Ely, A.; Arond, E.; et al. Transforming Innovation for Sustainability. Ecol. Soc. 2012, 17, 11. [CrossRef]

4. Olsson, P.; Moore, M.-L.; Westley, F.R.; McCarthy, D.D.P. The concept of the Anthropocene as a game-changer: A new context for social innovation and transformations to sustainability. Ecol. Soc. 2017, 22, 31. [CrossRef]

5. Steffen, W.; Richardson, K.; Rockström, J.; Cornell, S.E.; Fetzer, I.; Bennett, E.M.; Biggs, R.O.; Carpenter, S.R.; de Vries, W.; De Wit, C.A.; et al. Planetary boundaries: Guiding human development on a changing planet. Science 2015, 347, 1259855. [CrossRef] [PubMed]

6. Krausmann, F.; Fischer-Kowalski, M. Global Socio-metabolic Transitions. In Long Term Socio-Ecological Research: Studies in Society-Nature Interactions Across Spatial and Temporal Scales. Human-Environment Interactions 2; Singh, S.J., Haberl, H., Chertow, M., Mirtl, M., Schmid, M., Eds.; Springer: Dordrecht, The Netherlands, 2013; pp. 339-365.

7. Marsden, T. Towards a Real Sustainable Agri-food Security and Food Policy: Beyond the Ecological Fallacies? Polit. Q. 2012, 83, 139-145. [CrossRef]

8. Grin, J.; Rotmans, J.; Schot, J. Transitions to Sustainable Development: New Directions in the Study of Long Term Transformative Change; Routledge: New York, NY, USA, 2010.

9. Pahl-Wostl, C. A conceptual framework for analysing adaptive capacity and multi-level learning processes in resource governance regimes. Glob. Environ. Chang. 2009, 19, 354-365. [CrossRef]

10. Westley, F.; Olsson, P.; Folke, C.; Homer-Dixon, T.; Vredenburg, H.; Loorbach, D.; Thompson, J.; Nilsson, M.; Lambin, E.; Sendzimir, J.; et al. Tipping Toward Sustainability: Emerging Pathways of Transformation. Ambio 2011, 40, 762-780. [CrossRef] [PubMed]

11. Seyfang, G.; Smith, A. Grassroots innovations for sustainable development: Towards a new research and policy agenda. Env. Polit. 2007, 16, 584-603. [CrossRef]

12. Seyfang, G. Green shoots of sustainability: The 2009 UK Transition Movement Survey; University of East Anglia: Norwich, UK, 2009.

13. Howaldt, J.; Schwarz, M. Social Innovation: Concepts, Research Fields and International Trends. In Studies for Innovation in a Modern Working Environment_International Monitoring; Henning, K., Hees, F., Eds.; IMA/ZLW \& IfU: Aachen, Germany, 2010.

14. Howaldt, J.; Schwarz, M. Social Innovation and its Relationship to Social Change; TUDO-TU Dortmund University: Dortmund, Germany, 2016.

15. Murray, R.; Caulier-Grice, J.; Mulgan, G. The Open Book of Social Innovation; Young Foundation: London, UK, 2010.

16. Moulaert, F.; Martinelli, F.; Swyngedouw, E.; Gonzalez, S. Towards Alternative Model(s) of Local Innovation. Urban Stud. 2005, 42, 1969-1990. [CrossRef]

17. Folke, C.; Carpenter, S.R.; Walker, B.; Scheffer, M.; Chapin, T. Resilience Thinking: Integrating Resilience, Adaptability and Transformability. Ecol. Soc. 2010, 15, 20.

18. Westley, F.R.; Tjornbo, O.; Schultz, L.; Olsson, P.; Folke, C.; Crona, B.; Bodin, Ö. A theory of transformative agency in linked social-ecological systems. Ecol. Soc. 2013, 18. [CrossRef]

19. Avelino, F.; Wittmayer, J.M.; Pel, B.; Weaver, P.; Dumitru, A.; Haxeltine, A.; Kemp, R.; Jørgensen, M.S.; Bauler, T.; Ruijsink, S.; et al. Transformative social innovation and (dis)empowerment. Technol. Forecast. Soc. Chang. 2017. [CrossRef] 
20. Seyfang, G.; Haxeltine, A. Growing grassroots innovations: Exploring the role of community-based initiatives in governing sustainable energy transitions. Environ. Plan. C Gov. Policy 2012, 30, 381-400. [CrossRef]

21. Mezirow, J. Learning as transformation: critical perspectives on a theory in progress; Jossey-Bass: San Francisco, CA, USA, 2000.

22. Sage, C. The transition movement and food sovereignty: From local resilience to global engagement in food system transformation. J. Consum. Cult. 2014, 14, 254-275. [CrossRef]

23. Ingram, J.; Maye, D.; Kirwan, J.; Curry, N.; Kubinakova, K. Learning in the Permaculture Community of Practice in England: An Analysis of the Relationship between Core Practices and Boundary Processes. J. Agric. Educ. Ext. 2014, 20, 275-290. [CrossRef]

24. Ingram, J. Agricultural transition: Niche and regime knowledge systems' boundary dynamics. Environ. Innov. Soc. Transitions 2018, 26, 117-135. [CrossRef]

25. Sol, J.; van der Wal, M.M.; Beers, P.J.; Wals, A.E.J. Reframing the future: the role of reflexivity in governance networks in sustainability transitions. Environ. Educ. Res. 2017, 4622, 1-23. [CrossRef]

26. Pesch, U. Tracing discursive space: Agency and change in sustainability transitions. Technol. Forecast. Soc. Chang. 2015, 90, 379-388. [CrossRef]

27. Bauler, T.; Pel, B.; Backhaus, J. Institutionalization processes in transformative social innovation: Capture dynamics in the social solidarity economy and basic income initiatives. In Social Change and the Coming of Post-Consumer Society; Cohen, M., Szejnwald Brown, H., Vergragt, P., Eds.; Routledge: New York, NY, USA, 2017; pp. 78-94.

28. Wenger, E. Communities of Practice: Learning, Meaning, and Identity; Cambridge University Press: Cambridge, UK, 1999.

29. Wenger, E. Communities of Practice and Social Learning Systems. Organizations 2000, 7, 225-246. [CrossRef]

30. Wenger, E.; Snyder, W.M. Communities of practice: the organizational frontier. Harv. Bus. Rev. 2000, 78, 139-145.

31. Peltonen, T.; Lämsä, T. ' Communities of Practice ' and the Social Process of Knowledge Creation: Towards a New Vocabulary for Making Sense of Organizational Learning The Knowledge Creation Approach to Organizational Management. Probl. Perspect. Manag. 2004, 2, 249-262.

32. Hayden, J.; Rocker, S.; Phillips, H.; Heins, B.; Smith, A.; Delate, K. The Importance of Social Support and Communities of Practice: Farmer Perceptions of the Challenges and Opportunities of Integrated Crop—Livestock Systems on Organically Managed Farms in the Northern U.S. Sustainability 2018, 10, 4606. [CrossRef]

33. Rohde, M. Building Social Capital in an Iranian NGO Community System. In Social Capital and Information Technology; Huysman, M., Wulf, V., Eds.; MIT Press: Cambridge, UK, 2004; pp. 75-112.

34. Koliba, C.; Gajda, R. "Communities of Practice” as an Analytical Construct: Implications for Theory and Practice. Int. J. Public Adm. 2009, 32, 97-135. [CrossRef]

35. Walker, G. The role for "community" in carbon governance. Wiley Interdiscip. Rev. Clim. Chang. 2011, 2, 777-782. [CrossRef]

36. Hawken, P.; Lovins, A.B.; Lovins, L.H. Natural Capitalism: Creating the Next Industrial Revolution; Little, Brown and Co.: New York, NY, USA, 1999.

37. Jackson, T. Prosperity without Growth: Economics for a Finite Planet; Earthscan: London, UK, 2009.

38. Bergman, N.; Markusson, N.; Connor, P.; Middlemiss, L.; Ricci, M. Bottom-up, social innovation for addressing climate change. In Proceedings of the Sussex Energy Group Conference, Brighton, UK, 25-26 February 2010.

39. Wilson, G.A. Community resilience, transitional corridors and macro-scalar lock-in effects. Environ. Policy Gov. 2014, 24, 42-59. [CrossRef]

40. Giddens, A. The Constitution of Society: Outline of the Theory of Structuration; Polity Press: Cambridge, UK, 1984.

41. Shove, E.; Walker, G. Caution! Transition ahead: Policies, practice, and sustainable transition management. Environ. Plan. A 2007, 39, 763-770. [CrossRef]

42. Quist, J.; Tukker, A. Knowledge collaboration and learning for sustainable innovation and consumption: Introduction to the ERSCP portion of this special volume. J. Clean. Prod. 2013, 48, 167-175. [CrossRef]

43. Feola, G.; Nunes, R. Success and failure of grassroots innovations for addressing climate change: The case of the Transition Movement. Glob. Environ. Chang. 2014, 24, 232-250. [CrossRef] 
44. Smith, A. Green Niches in Sustainable Development: The Case of Organic Food in the United Kingdom. Environ. Plan. C Gov. Policy 2006, 24, 439-458. [CrossRef]

45. Ernstson, H.; Sörlin, S.; Elmqvist, T. Social movements and ecosystem services - the role of social network structure in protecting and managing urban green areas in Stockholm. Ecol. Soc. 2008, 13, 39. [CrossRef]

46. Kirwan, J.; Ilbery, B.; Maye, D.; Carey, J. Grassroots social innovations and food localisation: An investigation of the Local Food programme in England. Glob. Environ. Chang. Policy Dimens. 2013, 23, 830-837. [CrossRef]

47. White, R.; Stirling, A. Sustaining trajectories towards Sustainability: Dynamics and diversity in UK communal growing activities. Glob. Environ. Chang. 2013, 23, 838-846. [CrossRef]

48. Aiken, G.T. Community Transitions to Low Carbon Futures in the Transition Towns Network (TTN). Geogr. Compass 2012, 6, 89-99. [CrossRef]

49. Ferguson, R.S.; Lovell, S.T. Grassroots engagement with transition to sustainability: Diversity and modes of participation in the international permaculture movement. Ecol. Soc. 2015, 20, 39. [CrossRef]

50. Holland, L. Diversity and connections in community gardens: A contribution to local sustainability. Local Environ. 2004, 9, 285-305. [CrossRef]

51. Maschkowski, G.; Schäpke, N.; Langen, N.; Grabs, J. Learning from Co-Founders of Grassroots Initiatives: Personal Resilience, Transition, and Behavioral Change-A Salutogenic Approach. In Resilience, Community Action and Societal Transformation; Henfrey, T., Maschkowski, G., Penha-Lopes, G., Eds.; Permanent Publications: East Meon, UK, 2017; pp. 158-164.

52. Turner, B. Embodied connections: Sustainability, food systems and community gardens. Local Environ. 2011, 16, 509-522. [CrossRef]

53. Wals, A.E.J.; Rodela, R. Social learning towards sustainability: Problematic, perspectives and promise. NJAS Wageningen J. Life Sci. 2014, 69, 1-3. [CrossRef]

54. Wals, A.E.J. Social Learning Towards a Sustainable World: Principles, Perspectives, and Praxis; Wageningen Academic Publishers: Wageningen, The Netherlands, 2007.

55. Reed, M.; Evely, A.; Cundill, G.; Fazey, I.; Glass, J.; Laing, A.; Newig, J.; Parrish, B.; Prell, C.; Raymond, C.; et al. What is Social Learning? Ecol. Soc. 2010, 15, r1. [CrossRef]

56. Blackmore, C. Social Learning Systems and Communities of Practice; Blackmore, C., Ed.; Springer: London, UK, 2010.

57. Pahl-Wostl, C.; Craps, M.; Dewulf, A.; Mostert, E.; Tabara, D.; Taillieu, T. Social Learning and Water Resources Management. Ecol. Soc. 2007, 12, 5. [CrossRef]

58. Sterling, S. Transformative Learning and Sustainability: sketching the conceptual ground. Learn. Teach. High. Educ. 2011, 17-33.

59. Schenkel, A.; Teigland, R.; Borgatti, S.P. Theorizing structural properties of communities of practice: A social network approach. Proceedings of the Annual Meeting of the Academy of Management, Washington, DC, USA, 3-8 August 2001.

60. Contu, A.; Willmott, H. Re-Embedding Situatedness: The Importance of Power Relations in Learning Theory. Organ. Sci. 2003, 14, 283-296. [CrossRef]

61. Lesser, E.; Prusak, L. Communities of Practice, Social Capital and Organizational Knowledge. In Knowledge and Communities; Lesser, E.L., Fontaine, M.A., Slusher, J.A., Eds.; Butterworth Heinemann: Boston, MA, USA, 2000; pp. 123-131.

62. Woodhill, J. Sustainability, Social Learning and the Democratic Imperative: Lessons from the Australian Landcare Movement. In Social Learning Systems and Communities of Practice; Blackmore, C., Ed.; Springer: London, UK, 2010.

63. Ferguson, R.S.; Lovell, S.T. Permaculture for agroecology: Design, movement, practice, and worldview. A review. Agron. Sustain. Dev. 2014, 34, 251-274. [CrossRef]

64. Henfrey, T.W. Designing for resilience: Permaculture as a transdisciplinary methodology in applied resilience research. Ecol. Soc. 2018, 23, 33. [CrossRef]

65. Krebs, J.; Bach, S. Permaculture-Scientific Evidence of Principles for the Agroecological Design of Farming Systems. Sustainability 2018, 10, 3218. [CrossRef]

66. Morel, K.; Léger, F.; Ferguson, R.S. Permaculture. Encycl. Ecol. (Second Ed.) 2019, 4, 559-567.

67. Permaculture Association Course Prospectus. Available online: https://permaculture.org.uk/sites/default/ files/permaculture-association-course-prospectus-2018.pdf (accessed on 12 February 2019). 
68. ECOLISE Permaculture. Available online: https://www.ecolise.eu/permaculture-initiatives/ (accessed on 30 November 2018).

69. Gluch, P.; Johansson, K.; Räisänen, C. Knowledge sharing and learning across community boundaries in an arena for energy efficient buildings. J. Clean. Prod. 2013, 48, 232-240. [CrossRef]

70. Blatter, J.; Haverland, M. Designing Case Studies: Explanatory Approaches in Small-N Research; Palgrave Macmillan: Basingstoke, Hampshire, UK, 2012.

71. Flick, U.; Kardorff, E. von; Steinke, I.; Flick, U. A Companion to Qualitative Research; Sage Publications: London, UK, 2004.

72. Mayring, P. Qualitative Content Analysis. Forum Qual. Sozialforsch./Forum Qual. Soc. Res. 2000, 1.

73. Ulbrich, R. Practising Change(s): Analysing the German Niche of Permaculture with a Social Learning Perspective to Monitor Social Change in Sustainability Transitions. Master's Thesis, Leiden University and Delft University of Technology, Leiden, The Netherlands, Delft, The Netherlands, 2016.

74. Kennedy, D. Blick zurück nach vorn: Wie die Permakultur nach Europa kam, und welche Rolle David Holmgren dabei spielte. Available online: https:/ / oya-online.de/article/read/2479-.html\# (accessed on 12 February 2019).

75. Kennedy, D. Bill Mollison-Nachruf von Prof. Declan Kennedy. Available online: https:/ /www.permakulturakademie.com/2016/09/27/nachruf-von-prof-declan-kennedy/ (accessed on 12 February 2019).

76. Permakultur Institut e.V. Website Permakultur Institut e.V. und Permakultur Akademie. Available online: https: / / permakultur.de/ (accessed on 30 November 2018).

77. Avelino, F.; Wittmayer, J.M. Shifting power relations in sustainability transitions: A multi-actor perspective. J. Environ. Policy Plan. 2016, 18, 628-649. [CrossRef]

78. Avelino, F.; Wittmayer, J.; Haxeltine, A.; Kemp, R.; O’Riordan, T.; Weaver, P.; Loorbach, D.; Rotmans, J. Game Changers and Transformative Social Innovation. The Case of the Economic Crisis and the New Economy; DRIFT: Rotterdam, The Netherlands, 2014.

79. MiT What is the Municipality in Transition (MiT) Project about and Why is Important. Available online: http://municipalitiesintransition.org/about/ (accessed on 1 August 2018).

(C) 2019 by the authors. Licensee MDPI, Basel, Switzerland. This article is an open access article distributed under the terms and conditions of the Creative Commons Attribution (CC BY) license (http:/ / creativecommons.org/licenses/by/4.0/). 